\title{
Morphological and Anatomical Effects of Barban on Oat and Wheat Plants in Relation to Its Selectivity
}

\author{
Katsuichiro Kobayashi*, Yuji Yamasue, and Kunikazu UeKI
}

Faculty of Agriculture, Kyoto University, Kyoto.

\section{Summary}

Morphological and anatomical effects of barban [4-chloro-2-butynyl $N$-(3-chlorophenyl) carbamate], with foliar application, on oat (Avena sativa L.) and wheat (Triticum aestivum L.) shoots were investigated to clarify a selectivity.

In shoots of oat treated with barban, abnormal growth of apical meristem, leaf primodium, and the meristem which is responsible for lamina extention were observed. The herbicide induced hypertrophied and vacuolated cells, and disorderness in cell shape and in cell arrangement in these meristems. On the other hand, the distortion was little observed in wheat shoots.

These different morphological and anatomical effects of barban on oat and wheat shoots may be the main factors which contribute the different injury in two plant species.

* Present address: Laboratory of Herbicides, The Institute of Physical and Chemical Research, Wako, Saitama.

\section{ホティアオイによる重金属の収着について}

\author{
島根大学農学部 達山和紀・江川 宏・山岸建文
}

\section{1. 緒言}

ホテイアオイ (Eichhornia crassipes Solms) は湖沼 や河川の水路を閉塞し，また，有用植物の生育を阻害す る雑草であるが，窒素，リン酸などの吸収が旺盛である ので，近年はこれを水域の富栄養化防止に利用 $3,4,5) し ，$ 併せて, 回収されたホテイアオイを家畜の飼料として利 用りする試みも行われている。

一方，鈗山や工場の廃水などを污濁源とする各種の重 金属が水質の污濁物質として注目され，それらの除去法 に関心が持たれている2,10)。

筆者 ${ }^{6,7)}$ は, 1975 年以来, 林産廃棄物による重金属 の收着について検討して来たが，ホテイアオイを污濁水 からの重金属除去に利用多することも考えられるので, 鉛, カドミウムおよび銅について, そのホテイアオイに よる収着に関する予備的な実験を行い，二，三の結果が 得られたので，その概要を報告する。

\section{2. 鉛を混入した水耕液で育成したホテ イアオイの各器官における鉛の蓄積 および移行}

蜜業関係の工場廃棄物などを污濁源とする鉛による水 質污濁の例が少なくないので，まず鉛について検討した。

\section{実験材料および方法}

市販の塩ビ製衣裳ケース $(73 \mathrm{~cm} \times 43 \mathrm{~cm} \times$ 哚さ $23 \mathrm{~cm})$ に, 蒸留水または吉村氏液 $(1,000 \mathrm{~m} l$ 中の成分量, $\mathrm{Na}$ $\mathrm{NO}_{3}: 0.144 \mathrm{~g}, \mathrm{CaCl}_{2} \cdot 6 \mathrm{H}_{2} \mathrm{O}: 0.037 \mathrm{~g}, \mathrm{KH}_{2} \mathrm{PO}_{4}$ : $0.025 \mathrm{~g}, \quad \mathrm{MgSO}_{4} \cdot 7 \mathrm{H}_{2} \mathrm{O}: 0.050 \mathrm{~g}, \mathrm{KCl}: 0.025 \mathrm{~g}$, $\mathrm{FeSO}_{4}: 5 \times 10^{-6} \mathrm{~mol}, \mathrm{MnSO}_{4}: 1 \times 10^{-6} \mathrm{~mol}, \mathrm{pH}=6.8$ ) に $1 \mathrm{ppm}$ となるように鉛を混入した水溶液 $30 l$ を注入 して, 第 1 図に示した四つの実験区, すなわち, 吉村氏 液一鉛区と三つの蒸留水一鉛区を設けた。

各区にホテイアオイの成体株を 8 個体宛浮遊させた が，蒸留水一鉛区のうちの 1 区は黒色紙で覆って遮光 
し，1区は成体株の代わりに，ストロンによって分株し た分株後 2 週目の子株 16 個体を浮遊させた。そして, 実験開始後 4 週目まで, 毎週各区から 2 株宛, 子株の場 合は 4 株宛を無作為に取り出して, 根部, 浮木部, 葉部 の各器官に含まれている鉛の量を測定した。

ホテイアオイは松江市近郊で越冬, 自生している野生 のものを採取し, 島根大学農学部附属農場のガラス室内 で予備栽培したのち生体重のほぼ等しいものを選抜して 使用した。水耕液は毎週新鮮な液と交換し, また, 栽培 はガラス室内で行い, 昼温が $25^{\circ} \mathrm{C}$, 夜温が $15^{\circ} \mathrm{C}$ となる ように室温を調節した。水耕液に混入する鉛は酢酸鉛を 供試し, ホテイアオイの各器官に蓄積された鉛は硝酸, 硫酸, 過塩素酸法 ${ }^{11}$ によって抽出し, 原子吸光分光光度 計を用いて定量した。

\section{実 験 結 果}

第 1 図に示すと㧍り，成体株根部の鉛収着量は実験開 始後 1 週目において最高または最高に近い值を示し, 以 後の収着量の増減には一定の傾向は認められなかった。 しかし，子株を使用した区に执いては2 週目に最大収着 量に達し，成体株による収着を上回る值を示した。一 方, 古村氏液で調製した水耕液からの鉛の収着量は蒸留 水で調製した水耕液からのそれより低い值を示し，ま た，蒸留水一遮光区に打いても曝光区より収着量は低く 経過し，ホテイアオイによる鉛の収着は栽培条件によ一, て多少の差があるものと考えられた。

罒に示されるとおり, 供試ホテイアオイの実験開始時 における鉛の含有量は根部，浮木部，および葉部におい て乾燥重 $1 \mathrm{~g}$ 当たりそれぞれ $12.4 \mu \mathrm{g}, 9.7 \mu \mathrm{g}, 10.3 \mu \mathrm{g}$ であったが，浮木部および葉部の鉛含量は 4 週間の栽培 後においてもその増加はわずかで, 成体株, 子株ともそ れぞれの根部における含量に比較して著しく低い值を示 した。すなわち，根部に收着された鉛の浮木部，葉部へ の移行は少なく, 大部分は根の表面に吸着されている か，または根部に吸収，蓄積されているものと考えら 机, 最も収着量の少なかった吉村氏液区においても処理 前の約 5.3 倍に当たる $66.1 \mu \mathrm{g}$ の鉛が検出された。

\section{3. 重金属水溶液に浮遊させたホテイアオイ による重金属の収着}

上記の実験に扔いてホテイアオイが水耕液中の鉛を収 着することがわかったので，供試重金属にカドミウム招 よび銅を加え，溶液中からのこれらの重金属の除去につ いで., この実験を行った。

\section{実験材料および方法}

重金属は，鉛は酢酸鉛，カドミウム，銅はそれぞれ塩
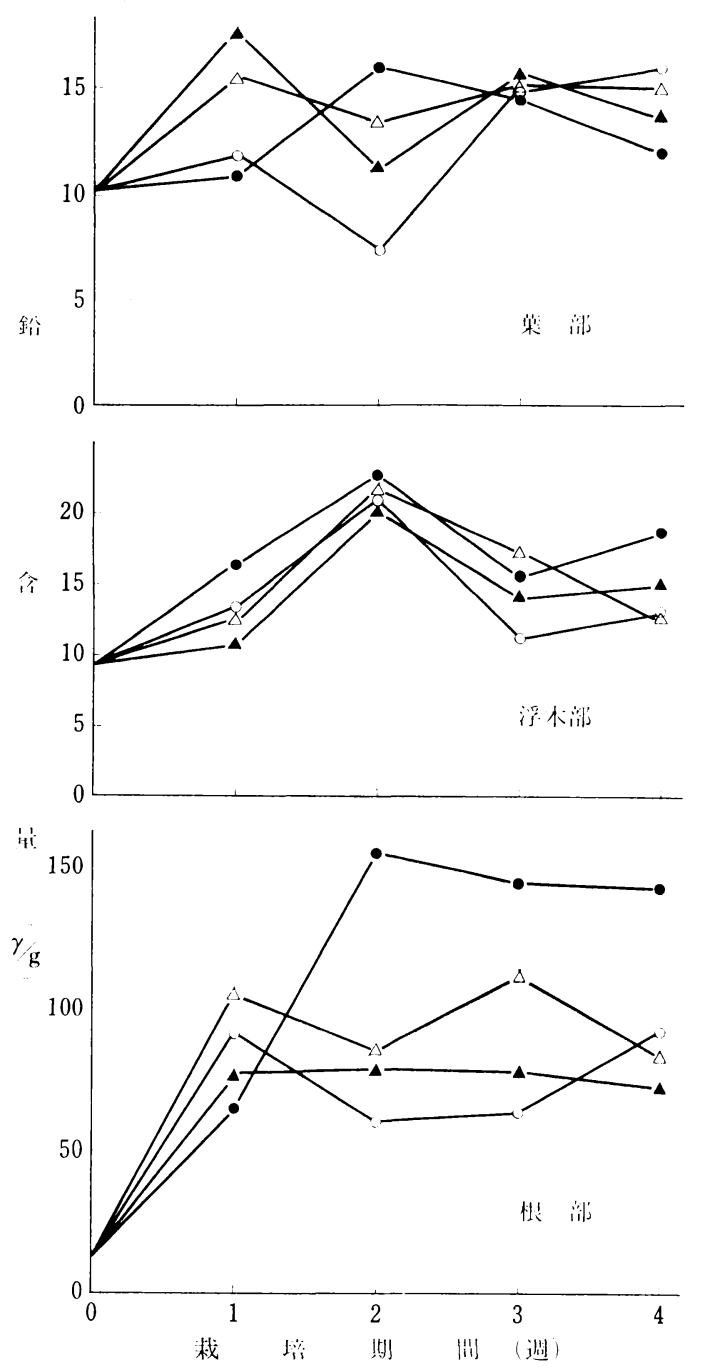

第 1 図 $1 \mathrm{ppm}$ の鉛水溶液で栽培したホテイアオイ 各部の鉛収着量

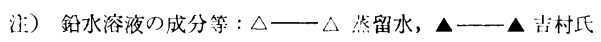
淮, ○一○华留水, 黒色紙で遮光, -——蒸留 水, 分株後 2 遇目の若株を使用

化カドミウム, 硫酸銅を供試した。 $3 l$ のガラス容器に $10 \mathrm{ppm}$ の各金属溶液 $2 l$ を注入し, これにホテイアオイ の成体株を 1 個体宛浮遊させた。

重金属溶液はスターラーで摚拌しながらチュービング ポンプを用いて原子吸光分光光度計へ導き, 溶液中の重 金属量の減少を連続的に測定することによってホテイア オイによる収着量を推定した。供試重金属溶液は 15 分 ごとに新鮮な溶液と交換し, ホテイアオイによる重金属 の收着を引き続き測定した。

\section{実 験 結 果}

第2図に示すと㧍り，いずれの重金属溶液に掞いても 
時間の経過にしたがって重金属残存量の減少が次第に緩 慢となったが，15 分後の鉛の収着量は供試した鉛の $91.5 \%$ に達し，また，カドミウムは $46.9 \%$, 銅では $73.0 \%$ がそれぞれ収着され，本実験の範囲ではホテイ アオイによる供試重金属の収着量は鉛が最も大で，次い で銅，カドミウムの順であることがわかった。

各重金属とも第 2 液，第 3 液との交換によってホテイ アオイによる収着が再び活発となったが，いずれの重金 属においても初めの第 1 液に浮遊させた場合に比較する と低い割合を示し，力ドミウムに拈いては第 3 液からの 収着は極めて少量にとどまった。

第 2 液または第 3 液からの供試重金属の収着量が，第 1 または第 2 液からのそれより低い值を示したのは，木 テイアオイによる重金属の収着量には限界があり，すで

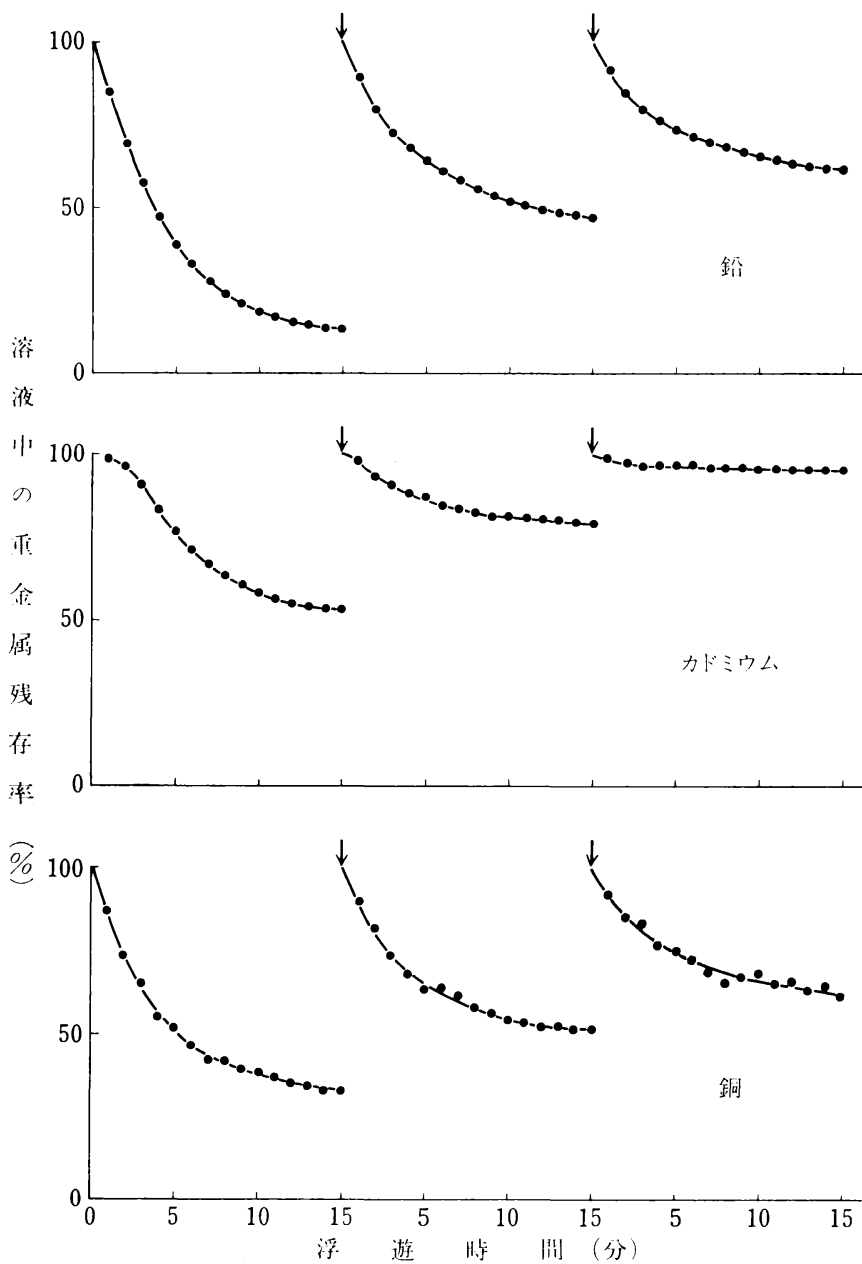

第 2 図 $10 \mathrm{ppm}$ の重金属溶液中に浮遊させたホテイアオイによる 供試重金属の収着

注）」は新鮮な重金属溶液との交換を示す。
に収着されている重金属が新たな収着を妨げるためであ ると考えられた。各重金属のこのような収着率の低下 は，初めに収着された重金属の種類によっても結果が異 なるものと考えられ，また水域を污濁させる重金属が必 ずしも 1 種類に限定されるものでなく，数種の重金属の 共存寸る場合が多いので，ホテイアオイによる重金属の 収着は，共存する他の重金属の影響を考虑に入れながら， 検討する必要があろう。そこで，まず，ホテイアオイを 浮遊させる重金属溶液を順次他の重金属液と交換し，初 めに用いた液の重金属がその後の重金属收着にどのよう な影響を及ぼすかを調査した。次に，重金属の混合溶液 を準備し，これにホテイアオイを浮遊させて，混合液か らの各種金属の収着量についても検討した。

第 1 表は，各単独の重金属溶液を順次交換した場合の 収着を示し，収着量は 15 分間浮遊させた のちの溶液中の重金属の減少量を供試ホテ イアオイの乾物重で除して求めたものであ る。第 1 液で鉛，カドミウム，または銅 第 1 表 異なる重金属溶液*に順次浮 遊させたホテイアオイによる 各重金属の収着量

\begin{tabular}{|c|c|c|}
\hline 第 1 液 & 第 2 液 & 第 3 液 \\
\hline \multirow{3}{*}{$\mathrm{Pb}(8.2) * *$} & $\mathrm{~Pb}(6.9)$ & $\begin{array}{l}\mathrm{Pb}(3.9) \\
\mathrm{Cd}(1.6) \\
\mathrm{Cu}(4.8)\end{array}$ \\
\hline & $\mathrm{Cd}(2.6)$ & $\begin{array}{l}\mathrm{Pb}(7.7) \\
\mathrm{Cd}(1.1) \\
\mathrm{Cu}(6.0)\end{array}$ \\
\hline & $\mathrm{Cu}(6.2)$ & $\begin{array}{l}\mathrm{Pb}(7.7) \\
\mathrm{Cd}(2.0) \\
\mathrm{Cu}(5.2)\end{array}$ \\
\hline \multirow{3}{*}{$\mathrm{Cd}(3.9)$} & $\mathrm{Pb}(10.5)$ & $\begin{array}{l}\mathrm{Pb}(9.1) \\
\mathrm{Cd}(-) \\
\mathrm{Cu}(-)\end{array}$ \\
\hline & $\mathrm{Cd}(1.4)$ & $\begin{array}{l}\mathrm{Pb}(9.9) \\
\mathrm{Cd}(0.3) \\
\mathrm{Cu}(7.1)\end{array}$ \\
\hline & $\mathrm{Cu}(6.0)$ & $\begin{array}{l}\mathrm{Pb}(8.3) \\
\mathrm{Cd}(0.4) \\
\mathrm{Cu}(4.7)\end{array}$ \\
\hline \multirow{3}{*}{$\mathrm{Cu}(4.8)$} & $\mathrm{Pb}(6.1)$ & $\begin{array}{l}\mathrm{Pb}(5.7) \\
\mathrm{Cd}(2.3) \\
\mathrm{Cu}(4.7)\end{array}$ \\
\hline & $\mathrm{Cd}(1.7)$ & $\begin{array}{l}\mathrm{Pb}(7.5) \\
\mathrm{Cd}(0.8) \\
\mathrm{Cu}(4.0)\end{array}$ \\
\hline & $\mathrm{Cu}(3.4)$ & $\begin{array}{l}\mathrm{Pb}(6.5) \\
\mathrm{Cd}\left(-\frac{1}{\mathrm{Cu}}(2.9)\right.\end{array}$ \\
\hline
\end{tabular}

* 重金属溶液の濃度 : $10 \mathrm{ppm}$

:k* 收着量 : $r / g$

を収着させたホテイアオイの第 2 液からの 鉛の収着量はそれぞれ $6.9 \mu \mathrm{g}, 10.5 \mu \mathrm{g}$, $6.1 \mu \mathrm{g}$ で，鈆の収着に対する阻害効果は 銅が最も大きく, 次いで鉛, カドミウムの 順であった。カドミウムの収着については カドミウム>銅>鉛，また銅の収着につい 
ては銅>カドミウム>鉛の順に強い阻害を示し，カドミ ウム，銅のいずれもそれぞれ同じ金属による阻害が強 く，また，いずれも鉛による阻害が弱いことがわかった。 第3 図は供試重金属の混合液からの収着を示したもの である。各重金属 $10 \mathrm{ppm}$ を含む混合液を調製し，これ にホテイアオイを浮遊させた。収着量は前記と同様，ホ

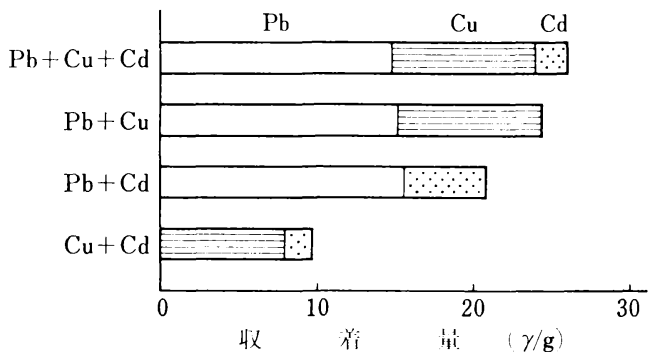

第 3 図各 $10 \mathrm{ppm}$ の重金属の混合液に浮遊させた ホテイアオイによる各重金属の収着量

テイアオイの乾物重当たりの重金属量で示した。眓に示 すとおり, 混合液中からの収着は, 第 2 図の各重金属溶 液からの収着と同様に鉛が最も多く, 次いで銅, カドミ ウムの順であった。また，カドミウム，銅の収着は鉛に よる阻害が少なく，カドミウムの収着は銅の存在によっ て強く阻害された。

\section{4. ホティアオイの重金属収着に及ぼす 二, 三の要因}

前記の実験（第 1 図）において，ホテイアオイによる 鉛の収着が栽培条件によって多少の差があるものと考え られたので，今回はまず供試重金属溶液の温度， $\mathrm{pH}$ と 収着量との関係を調査した。

\section{実験材料および方法}

液温については容器の周囲を水片で囲み, $10^{\circ} \mathrm{C}$ に冷 却した区，常温区 $\left(20^{\circ} \mathrm{C}\right)$, および，通常の水域では考 えられない水温であるが，高温区すなわち湯浴によって $60^{\circ} \mathrm{C}$ に加温した区，の 3 区を設けた。実験中の液温は初 めに設定された温度の $\pm 2{ }^{\circ} \mathrm{C} の$ 範囲で維持された。

重金属は鉛, カドミウム, 銅について検討し, 実験 II と同様の方法でホテイアオイによる重金属の収着を測定 した。 $\mathrm{pH}$ にいては鉛の水溶液のみについて実験し, その $\mathrm{pH}$ を塩酸または苛性ソーダを用いて調節した。

\section{実 験 結 果}

第 4 図に示すとおり，いずれの重金属を供試した場合 も $20^{\circ} \mathrm{C}$ 区における収着量が $10^{\circ} \mathrm{C}$ の区のそれを上回り， 通常の水域環境では高温区における収着が高い結果を示 すものと考えられた。しかし，60 $\mathrm{C}$ 区においては，カド ミウムの場合には実験開始後 20 分まで常に他の 2 区に
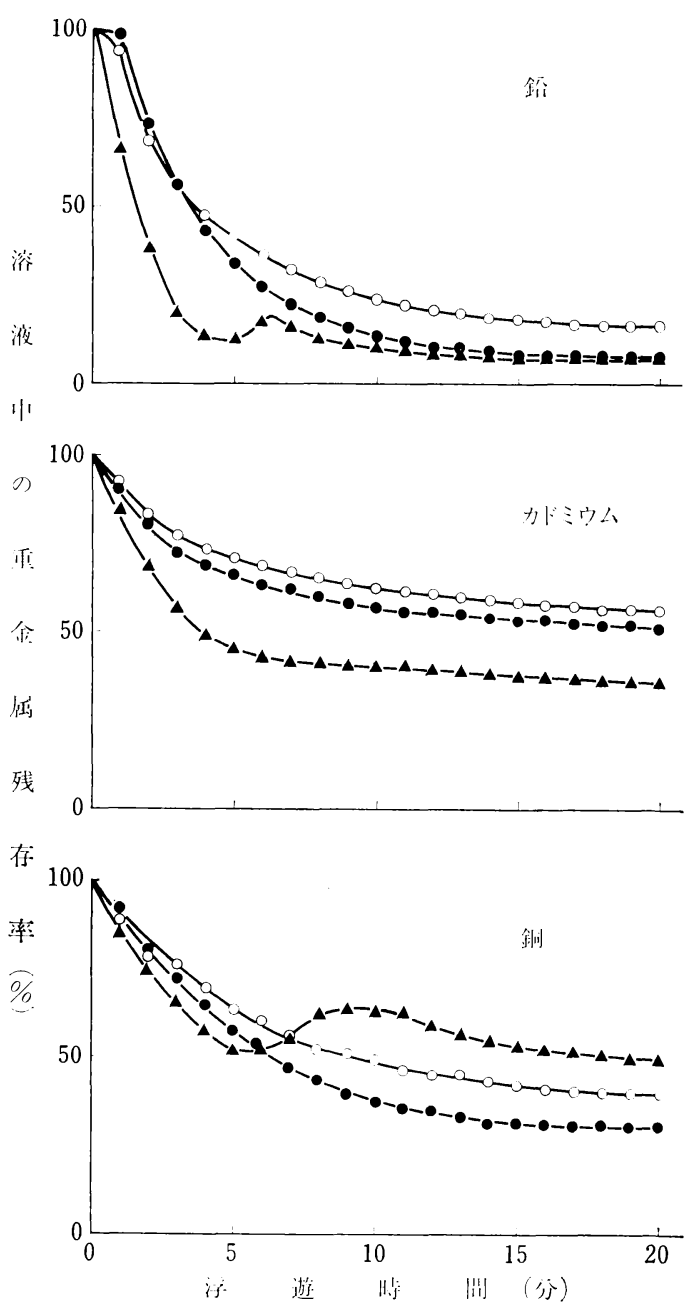

第 4 図重金属水溶液に浮遊させたホテイフオイに 上る重金属の収着と水温との関係

洼） $\longrightarrow \mathrm{O} 10^{\circ} \mathrm{C} \longrightarrow 20^{\circ} \mathrm{C}, \boldsymbol{\Delta}-\boldsymbol{\Delta} 60^{\circ} \mathrm{C}$

おける収着量を上回ったが，鈆，銅の場合は一度収着さ れた鉛または銅の一部が再び溶液中に溶脱するものと考 えられ, 特に銅においては, 7 分以降においては $10^{\circ} \mathrm{C}$, $20^{\circ} \mathrm{C}$ の各区よりもむしろ低い収着量で経過した。

次に, 鉛の水溶液についてその $\mathrm{pH}$ とホテイアオイに よる収着量との関係を調査したが，第 5 図に示すとお り，中性および $\mathrm{pH}=5$ の区においてはほぼ同様な収着 が認められたが， $\mathrm{pH}=3$ 区ではさきの両区に比較して 低い収着量にとどまり，ホテイアオイによる重金属の収 着は酸性の強い水域では期待できないことがわかった。 $\mathrm{pH}=9$ の区においては収着が極端に劣ったが，これは 供試した酢酸鉛が不溶性の水酸化鉛として沈澱し，その ために収着されなかったものと考えられた。 


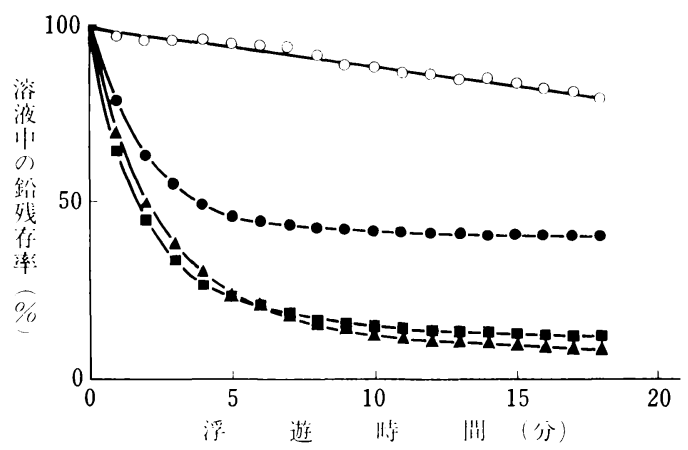

第 5 図 鉛水溶液に浮遊させたホテイアオイによる 鉛の収着と水溶液の $\mathrm{pH}$ との関係

㴤)

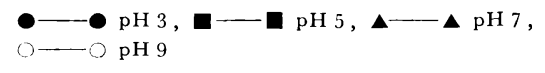

\section{5. 考察}

水質を污濁させている重金属には, カドミウム, 銅, 鈆, ヒ素，亜鉛，ニッケル，クロム，水銀など各種のも のが考えられるが，今回は鉛，銅，およびカドミウムを 対象に, そのホテイアオイによる収着, 除去の可能性を 検討した。

ホテイアオイを供試するに当たって最も問題となるの は供試株の個体差であろう。本実験ではガラス室内の予 備栽培によってその生育段階を調整し, さらに生体重の 差が $5 \mathrm{~g}$ 以内のものを選抜して供試した。これらの供試 株は乾燥重においてもその差が $0.5 \mathrm{~g}$ 以内にとどまった が，第 1 図に示したとおり，ホテイアオイによる重金属 の収着は主として根部によって行われるので，根部の表 面積などが重要な要因となろう。ホテイアオイ供試株の 選抜法は今後の検討課題として残されるが，本研究の範 囲では，ホテイアオイは重金属液中から種々の重金属を 収着し，その収着量は重金属の種類によって異なること がわかった。

重金属の収着は，溶液中に共存する他の物質によって 影響されるようである。第 1 表および第 3 図に示すとお り，供試重金属の収着量は先に収着され，または共存す る重金属の種類によって異なる值を示し, 収着に当たっ ての重金属間の競合に大小があることが認められた。こ れらの違いは各重金属の収着機構が関与するものと考え られるが，今回の実験では検討するに至らなかった。

活濁水中における他物質の影響は, 重金属に限らず他 の物質についても考えられる。第 1 図に示すと拈り，栄 養塩を含んだ溶液中からの鉛の収着は, 蒸留水で調製し た溶液からの収着量より劣っており, 他の成分の存在が 重金属の収着に影響を及ぼしていることが考えられた。 このような他物質の存在は一般の水域で常に起こりうる
ことであるので, 水域の污濁物質として考えられる種々 の成分について，単独あるいは混在している状態での試 験が今後必要とされる。第 4 図に示したとおり，高温区 のホテイアオイによる銅および鉛の収着曲線は常温区等 のそれと異なる結果を示した。これはホテイアオイの高 温障害がその重金属収着能に何らかの影響を及ぼしたも のと考えられ，ホテイアオイの生物としての機能や生育 状況等は重金属の収着量と密接な関係があるようであ る。第 1 図に示したとおり, 栽培中の遮光は鉛の収着量 を低下させたが, 遮光はホテイアオイの吸水, 蒸散量に 影響し，これが鉛の収着にも影響を及ぼしたものであろ う。また，子株の鉛の収着は成体株のそれを上回る值を 示した。さきに植木ら ${ }^{9}$ は水耕液の成分量の違いによっ てホテイアオイの生育が異なることを報告しており，ホ テイアオイによる重金属の収着, 除去を一般の水域で実 施する場合は，ホテイアオイ自体の生育との関係につい て十分調査する必要があろう。

本実験は，まず重金属がホテイアオイによってどの程 度收着されるかを検討したもので，栽培期間も短く，特 に鉛，カドミウム，銅水溶液からのこれらの収着につい ては短時間の処理による結果を取りまとめたものである ので，一般水域での污濁水の浄化に利用することの可否 について今直ちに結論を出すには至らない。今後，収着 に及ぼす種々の要因について，な険討する予定であ る。また，ホテイアオイの回収と，二次公害の防止を配 虑した処理の方法についても今後の課題であろう。

\section{6. 要約}

ホテイアオイを用いた污濁水からの鉛，カドミウム， 銅の除去の可能性を検討した。

初めに $1 \mathrm{ppm}$ の鉛を混入した水耕液でホテイアオイ を栽培し，鉛のホテイアオイ体内における分布を調査し た結果，根においては栽培開始後 1 週目に鉛の含量は最 高值に達し, その後の増減には一定の傾向は認められな かった。根に取り込まれた鉛の浮木部，葉部への移動は 少ないものと考えられ，これらの器官での鉛の含量は根 部のそれよりはるかに低い值であった。

次に, 各 $10 \mathrm{ppm}$ の鉛，カドミウム，および銅の水溶 液，またはその混合溶液中からのホテイアオイへの収着 量を比較した結果，鉛が最も良く収着され，次いで銅， カドミウムの順であった。これらの重金属の収着は他の 重金属によって妨害され，また，強酸性液の場合，液温 の低い場合も収着量が少ないことがわかった。

\section{引用文 献}

1) Pirie, N. W.: Water Hyacinth: a Curse or Crop ? NATURE 
185, 116 (1960).

2) Randall, J. M., R. L. Bermann, V. Garrett and Waiss, JR. A. C.: Use of Bark to Remove Heavy Metal Ions from Waste Solutions. Forest Products J. 24 (9), 80 84 (1974).

3) Rogers, H. H. and D. E. Davis: Nutrient Removal by Waterhyacinth. Weed Science 20 (5), 423 428 (1972).

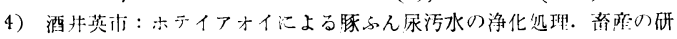
究 27 (4)，533〜 538 (1973).

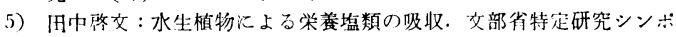
シウム, 肥料汇上る陸水の励濁と指標植物, 要爫集. 91 97 (1976).

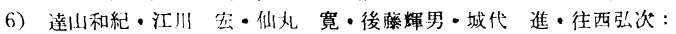

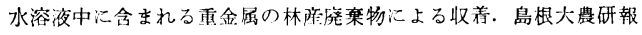
9, 58〜62 (1975).

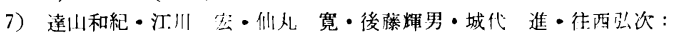

污摆水中に含まれる重金属の林颜廃裹物による除去。鳥根大農研報 9, $63 \sim 67$ (1975)

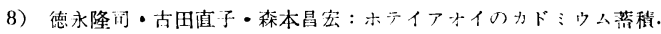
葦生化学 22 (4), 234 239 (1976).

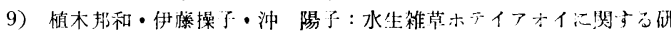

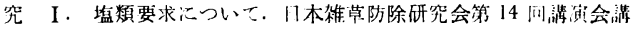
湍要告. 184 186 (1975).

10) Waiss, A. C., M. E. Wilfy, J. A. Kuhxile, A. L. Potter and R. M. MCCREADY: Absorption of Mercuric Cation by Tannins in Agricultural Residues. J. Env. Quality 2, 369 371 (1973).

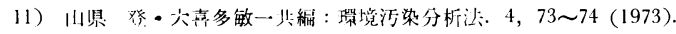

(1977 年. 6 月 6 日受付)

\title{
Sorption of Heavy Metals by the Water Hyacinth from the Metal Solutions
}

\author{
Kadzunori Tatsuyama, Hiroshi Egawa and Takefumi Yamagishi
}

Faculty of Agriculture, Shimane University, Matsue, Shimane

\section{Summary}

Removal of lead, cadmium and copper using water hyacinth (Eichhorina crassipes Solms) from the solution polluted by the metals were studied. Lead content of the plant roots increased as a result of culture on the solution containing $1 \mathrm{ppm}$ of the metal. The metal content of the root reached to the maximum a week after the begining of the cultivation, and then remained at the constant leavel. It seems that translation of the metal into the stem or leaves was less than the amount in the roots.

In other experiments, amount of the metals taken up by water hyacinth from the solutions containing $10 \mathrm{ppm}$ of lead, cadmium or copper, and from thier mixed solutions were determined. Lead was taken up in the highest amount, followed by copper and cadmium. Sorption of a metal was inhibited at the following conditions, namely, in the presence of other metals, at the strong acid side of the solution, and at low temperature of the solution.

\section{短 報}

\section{数種雑草種子の休眠覚醒の貯蔵条件による差異}

\author{
農林省農事試験場 片 岡 孝 義, 韓国農村振興庁作物試験場 金 昭 年 \\ Takayoshi KataOKA* and So Yeon KIM**: Effects of Storage \\ Conditions on Dormancy-awakening of Several Weed Seeds
}

種子の休眠覚醒過程が解明されている雑草は少なく， そのために, 雑草種子の自然条件下における生存状態を 解明する上でも, 試験に休眠覚醒種子を供試する上で
も，支障を来している。そこで，筆者らは，水田雑草を 中心に 7 種の雑草の休眠種子について, 貯蔵条件による 休眠覚醒の差異を調べた。

* Central Agricultural Experiment Station, Konosu, Saitama.

** Crop Experiment Station, Office of Rural Development, Suweon, Korea. 